\title{
EVALUATION OF THE COMMUNITY-BASED ECOTOURISM DEVELOPMENT STATUS IN THE AKSU-JABAGLY NATURE RESERVE, KAZAKHSTAN
}

\author{
Imanaly AKBAR* \\ China and University of the Chinese Academy of Sciences, State Key Laboratory of Desert and Oasis Ecology, Xinjiang Institute of Ecology \\ and Geography, Chinese Academy of Sciences, Urumqi 830011, Beijing 100049, China, e-mail: yimanaili_akebaier@yahoo.com
}

\section{Zabira Kazbekkyzy MYRZALIYEVA}

SILK WAY International University, Department of Modern History of Kazakhstan and Geography, Kazakhstan, e-mail: zabira2011@ mail.ru

Akmaral Zhaksybekkyzy TAZHEKOVA

South Kazakhstan State Pedagogical University, Department of Geography, Shymkent 160000, Kazakhstan, e-mail: tazhekova@mail.ru

\author{
Altynbay Tagabaiuly SAULEMBAYEV
}

South Kazakhstan State Pedagogical University, Faculty of Natural Sciences, Kazakhstan, e-mail: altynbai_saulembaev@mail.ru

\section{Rabiga Nokerbekkyzy KENZHEBAY}

South Kazakhstan University named after M.Auezov, Department of Biology and Geography, Kazakhstan, e-mail: mega.rabiga@list.ru

\author{
Citation: Akbar I., Myrzaliyeva Z.K., Tazhekova A.Z., Saulembayev, A.T., \& Kenzhebay R.N. (2021). EVALUATION OF THE \\ COMMUNITY-BASED ECOTOURISM DEVELOPMENT STATUS IN THE AKSU-JABAGLY NATURE RESERVE, \\ KAZAKHSTAN. GeoJournal of Tourism and Geosites, 35(2), 381-389. https://doi.org/10.30892/gtg.35216-662
}

\begin{abstract}
Many stakeholders believe that developing community-based ecotourism (CBET) in vulnerable nature reserves is an effective method of ensuring greater conservation of natural and cultural resources, empowering host communities, and improving their socio-economic well-being. This paper assesses the current status of the CBET development in the Aksu-Jabagly nature reserve (NR), located in the south part of Kazakhstan. In order to understand ecotourism development status, 222 representative households from two neighboring communities of Aksu-Jabagly NR were surveyed with 5-point Likert scale questions. At the same time, two tourism relevant experts were interviewed. The results of examining the three indicators (community tourism relevance, community participation rank, and community empowerment), showed that the neighboring community relevance with the tourism in AksuJabagly NR was low, the community residents' participation rank in tourism was also at the lower level, and the community's empowerment status is not ideal. As a result, we initially asserted that the status of CBET development in Aksu-Jabagly NR is not well, in particular, the positive economic and social impact of tourism development is not so obvious.
\end{abstract}

Key words: CBET, relevance, participation, empoverment, nature reserve, Aksu-Jabagly, Kazakhstan

\section{INTRODUCTION}

\section{Community-based ecotourism (CBET) development}

If tourism practices are not properly monitored, they can deplete natural resources and exploit the work of local communities. The approach to CBET projects should be part of a larger community development strategy and carefully planned. It is universally recognized that community-based tourism initiatives reduce poverty not only by increasing incomes, but also by providing rural communities with the tools and education for long-term critical thinking and decision-making. Sustainable eco-tourism is contingent on the 4Es: environmental conservation, equity, education, and economic benefits. In other words, eco-tourism is a tourism activity that can reduce environmental degradation during economic development and support environmental protection, social justice and environmental education (Powell and Ham, 2008). The participation of the local community is needed to create ecotourism. Such communities are expected to provide support for ecotourism activities. Therefore, they will recognize their role in preserving the protected natural areas. Ecotourism can be an incentive to protect the environment, if it leads to positive economic change (Stronza and Gordillo, 2008). The premise is that ecotourism depends on maintaining fascinating natural landscapes and abundant flora and fauna; therefore, helping communities make money from ecotourism can provide not only conservation motivation but also economic alternatives to destructive activities (Kiss, 2004). CBET essentially helps to preserve biodiversity and wildlife, and believes that people living in natural areas should be involved in conservation decisions (Reimer and Walter, 2013). CBET is run by the community, management decisions are made by local people and the profits go directly to the community (Khanal and Babar, 2007). CBET is a type of ecotourism that focuses on the development of local communities and allows local people to significantly control its development, management and participation, at the same time, most of the profits should remain in the community (Denman, 2001; Wood, 
2002). CBET has become an important tool for protecting biodiversity, based on the principle that the protected biodiversity reserve must generate economic benefits for itself, especially for the local people (Kiss, 2004). CBET destinations bring potential benefits to individuals, communities and the entire country in terms of creating employment opportunities, foreign exchange earnings and improving the well-being of local residents (Mbaiwa, 2003). Development organizations see CBET as a potential source of economic development and poverty eradication, especially in rural areas with limited agricultural potential. For example, in the past decade, CBET in East Africa and Southern Africa has seen the strongest growth in the global market because of its positive economic impact on the people of the region, making it an essential industry (Organization, 2001). CBET has increased local income and built the local economy by protecting the local ecosystem and culture. However, only when the community sees the benefits of ecotourism development, and when the development of ecotourism does not harm their environment and affect their main source of livelihood, will ecotourism get support among the local community (Alexander, 2000; Walpole and Goodwin, 2001; Salafsky et al., 2001).

CBET and responsible tourism should be part of a sustainable development strategy. Environmental sustainability includes present generations' preservation of natural heritage and biodiversity, and the preservation of important environmental processes for future generations (Törn, 2007). Moreover, from a social point of view, nature-based ecotourism employs the local population and promotes the development of the regional economy, as well as assures the quality of life of local population, preserves environmental values and provides quality services to tourists (Williams and Fennell, 2002). The proper organization of CBET always meets all the criteria of the sustainable tourism development. Hipwell (2007) proposed a framework of six standards for sustainable CBET: 1) tourism activities must be small enough to be completely managed by the community without external support; (2) broad representatives of community members should actively participate in the project; (3) the project must benefit the entire community; (4) the project must comprehensively improve the community members' life quality; (5) the awareness of conservation value must be improved; and (6) the maintenance or enhancement of local culture should be promoted. These criteria are indicated to be the particular characteristic of successful CBET projects (Hipwell, 2007). In the case of nature-based tourism areas, the local community closest to the area where tourism development is permitted are often the main stakeholders, because as human resources, they participate in various activities in tourist attractions. To understand how sustainable tourism benefits local communities, it is essential to examine the extent to which local communities can participate in tourism planning and related decision-making processes and to assess how tourism can contribute to their well-being. The aim of this paper is to explore the development status of the CBET in the Aksu-Jabagly NR through examining the tourism relevance of two main neighboring communities of natural heritage tourism destination, the local community's tourism participation rank, and the empowerment level of the local community.

\section{An overview of the study area: Aksu-Jabagly Natural Reserve}

Tien Shan is the one of the biggest mountain systems in Central Asia. It spreads for 2,500 kilometers (1,500 miles) and consists of several units of mountains. Aksu-Jabagly (also spelled as Aksu-Zhabagly) NR is situated in the north west of Talas, Alatau and Ogem mountains. Aksu-Jabagly NR was opened by the conference of Soviet-Kazakh National Commissioners on July 14, 1926. At the conference it was decided that the Aksu and Jabagly's rivers, trees, plants and animals living there be designated as a historical untouched nature preserve. The area of reserve changes from year to year but currently has a territory of approximately 131,934 hectares (326,015 acres). Aksu-Jabagly NR borders Kyrgyzstan and Uzbekistan. Reserve's territory covers Tulkibas, Tolebi, Baidibek regions in South Kazakhstan oblast and the Juali region in Djambyl oblast. Aksu and Jabagly are the two main rivers that flow through the reserve. There are 27 lakes in the reserve which are all situated at the height where the snow doesn't melt. Aksu-Jabagly NR is rich with rare and endangered species of animals. Since the last count there are 267 types of birds, 52 types of mammals, 11 types of vermin and 2124 types of insects. Aksu-Jabagly NR is rich

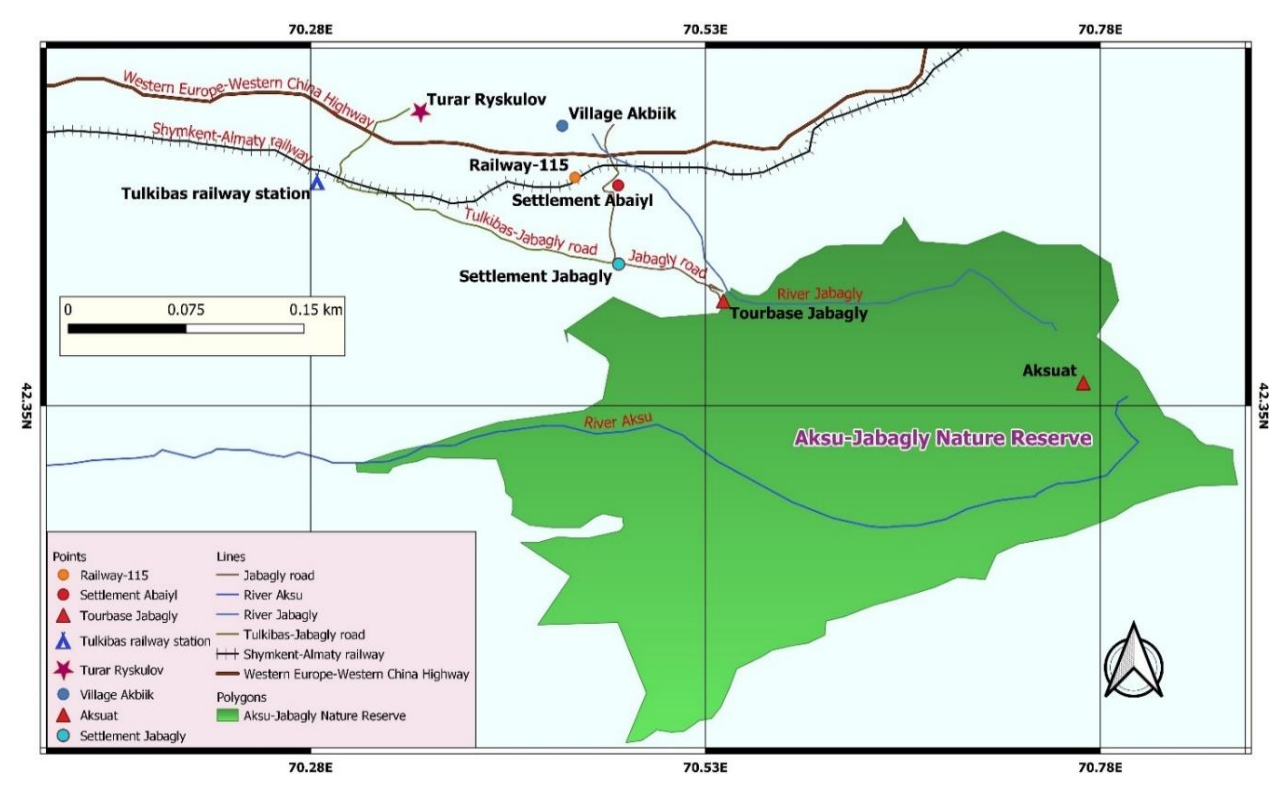

Figure 1. The administrative map of the study area with plants and trees. There are 63 types of moss, 64 types of algae, 235 types of mushrooms, 62 types of branches, 17 types of trees and 3 types of spruces. It contains $25 \%$ of all Kazakhstan's plants (Kovshar, 2016). And the NR was officially listed on UNESCO as a part of the Western Tien-Shan natural world heritage site under the criteria of (vii) and (x) in 2016. The Aksu-Jabagly heritage site is located among four districts of two administrative oblasts in the most densely populated region of Kazakhstan, with total population about 3 million people. Approximately 150,000 people live in the transition area 
of the nature reserve (Kazakhstan National Committee, 2014). In the last 10 years, ecological tourism has become highly popular in the reserve, mainly due to tourism for bird watching and plant research and wildlife seeing, and the $59 \mathrm{~km}$ area of Tulkibas is located along with the Western Europe-Western China (WE-WC) Highway (Figure 1), it provides convenience for auto travel to this nature reserve (Akbar et al., 2020b).

\section{MATERIALS AND METHODS}

\section{Data Collection and Methodology}

In 2019, we conducted a similar comparative study called the "Local residents' participation in tourism at a world heritage site and limitations: A case of Aksu-Jabagly natural world heritage site, Kazakhstan”. The aim was to indicate two main neighboring communities' participation status and their barriers to participation. This is a case study integrating quantitative and illustrative qualitative methods in data collection and analysis. A questionnaire survey was used to evaluate the two main neighboring communities' tourism relevance degree. At the same time, interviews with relevant experts (A tourism researcher of the L.N. Gumilyov Eurasian National University, the mayor of the village Jabagly and the scientific research department director of AksuJabagly NR office) were used to indicate neighboring communities' participation rank and empowerment status in the CBET development in Aksu-Jabagly NR. The Aksu-Jabagly NR was selected because it has been identified as a more CBET developed area among nature reserves in Kazakhstan. In the initial stage of research, interviews were held in city Shymkent (the closest location to Aksu-Jabaly NR and the third largest city in Kazakhstan), with 3 informants representing tourism companies which were involved in ecotourism in the Aksu-Jabagly NR. Our advance study area observation helps to effectively perform questionnaire surveys and interviews for the primary data analysis. Field research was conducted in about 3 week-long visits to the Aksu-Jabagly ecotourism destination from the $2^{\text {nd }}$ of March to $22^{\text {nd }}$ of March, 2019, and the respondents were selected from settlement Jabagly (166 people out of 1571 economically active population) and settlement Abaiyl (56 people out of 275 economically active population). Data was collected in Aksu-Jabagly NR from multiple sources: questionnaire survey, direct observation, interviews. All fieldwork was conducted by the first author (Imanaly Akbar), who is a doctoral student at the University of the Chinese Academy of Sciences. Focus respondents were the key CBET stakeholders including eco-tour guides, guesthouse owners, cooks, taxi drivers etc., who are representatives both from settlement Jabagly and Abaiyl. At the same time, in order to understand neighboring communities' empowerment status and participation rank in tourism comprehensively, the aforementioned relevant experts were also interviewed. Villagers who are responsible for the protection work of this ecotourism destination were interviewed as well. Survey questions about tourism relevance of the neighboring communities include current engaging industries, suitable industries for the nature reserve, reselected industries, and concerns about tourism development. When we discuss and illustrate the comparison results of tourism relevance indicators, the "Distance Decay Law" was used in our study. The map of the community participation level and community empowerment map was also applied to show the status of Aksu-Jabagly neighboring communities' tourism-participation and empowerment. Accordance with the results from the analysis of the above indicators, we evaluated the sustainability of CBET development in the Aksu-Jabagly NR.

\section{Demographic characteristics of respondents}

Table 1 shows that out of the 222 respondents, 166 were from the Jabagly settlement and 56 were from the Abaiyl settlement. Since men generally go out to work in remote villages to earn money while women do housework and raise children, the number of men we interviewed is almost twice as large as that of women, with $66.3 \%$ (from Jabagly) and 67.9\% (from Abaiyl) respectively. The highest number of respondents was the middle age group (35-54) with (53.0\%) from Jabagly and (48.2\%) from Abaiyl respectively, followed by the young (18-34), with 36.2\% (Jabagly) and 39.3\% (Abaiyl). And the lowest number of respondents was the elder group ( $\geq 55)$, with (10.8\%) from Jabagly and (12.5\%) from Abaiyl respectively. Nearly all respondents were Kazakhs: $91.6 \%$ were from Jabagly and $92.8 \%$ from Abaiyl were interviewed, respectively. At the same time, survey questions were answered by $4.8 \%$ Russian ethnic people and 3.6\% other ethnic groups in Jabagly and 3.6\% Russian and 3.6\% other ethnic groups in Abaiyl. Most of the respondents had the middle (school or college) education, with $85.5 \%$ of Jabagly and $89.3 \%$ of Abaiyl while only 14.5\% (Jabagly) and 10.7\% (Abaiyl) of those who have received higher education (university or above).

\section{RESULTS AND DISCUSSIONS}

\section{Community-based ecotourism in the Aksu-Jabagly NR}

Sustainable tourism enables people to participate and benefit from it. Developing sustainable tourism activities can generate income for local residents and build community facilities. Not only local people will benefit from sustainable tourism resources, but the private sector will also benefit from it (Polnyotee and Thadaniti, 2015). In order to achieve sustainable tourism, tourism development should recognize and encourage a higher level of local community satisfaction. And to improve the sustainability in Aksu-Jabagly heritage tourism destination, opportunities of engaging in the tourism sector should be equally given to local residents (Akbar et al., 2020a). To measure the development status of tourism types in a designated area, it is necessary to study how the community as a whole involved in the development of the area as a tourist destination. Therefore, we consider the following indicators to determine the status of CBET development in the Aksu-Jabagy NR: the relevance of the neighboring communities with tourism; tourism participation rank of neighboring communities; empowerment of neighboring communities.

\section{Tourism relevance of the neighboring communities}

Current engaging industry comparison: As can be seen from Table 2, the settlement Jabagly in the buffer zone of the Aksu-Jabagly NR was typically dominated by animal husbandry (48.8\%) and farming (23.6\%), whereas settlement Abaiyl was other industry-dependent communities (more than half of the total population in Abaiyl settlement engaged in other industries 
with 53.6\%). As far as the two settlements' tourism involvement is concerned, few people participated in tourism activities in both settlements. Comparing tourism involvement of two settlements, there were about 5 times more residents in Jabagly settlement (10.2\%) engaged in tourism than in settlement Abaiyl (2\%). During our study area investigation, we found that Jabagly had more land available for animal husbandry and farming compared to Abaiyl, and we also found that the settlement Abaiyl is located along the railway. Thus, the current engaging industry of Jabagly's people was animal husbandry and farming, while most Abaiyl's people were engaging in other industries due to the lack of arable land.

Table 1. Details of resident sample responses $(\mathrm{n}=222)$

\begin{tabular}{|c|c|c|}
\hline \multirow[t]{2}{*}{ Characteristics } & $\begin{array}{l}\text { Jabagly } \\
(\mathrm{n}=166)\end{array}$ & $\begin{array}{l}\text { Abaiyl } \\
(\mathrm{n}=56)\end{array}$ \\
\hline & Percentage & Percentage \\
\hline \multicolumn{3}{|l|}{ Gender: } \\
\hline Male & 66.3 & 67.9 \\
\hline Female & 33.7 & 32.1 \\
\hline \multicolumn{3}{|l|}{ Age (years): } \\
\hline Young (18-34) & 36.2 & 39.3 \\
\hline \multicolumn{3}{|l|}{ Middle age } \\
\hline$(35-54)$ & 53 & 48.2 \\
\hline Elder $(\geq 55)$ & 10.8 & 12.5 \\
\hline \multicolumn{3}{|l|}{ Ethnicity } \\
\hline Kazakh & 91.6 & 92.8 \\
\hline Russian & 4.8 & 3.6 \\
\hline Other & 3.6 & 3.6 \\
\hline \multirow{3}{*}{\begin{tabular}{|l|}
\multicolumn{1}{|c|}{ Education: } \\
Middle (school \\
or college) \\
High (university \\
or above)
\end{tabular}} & & \\
\hline & 85.5 & 89.3 \\
\hline & 14.5 & 10.7 \\
\hline
\end{tabular}

Table 2. Comparison of residents' tourism relevance in neighboring communities (Source: authors' own work)

\begin{tabular}{|c|c|c|}
\hline What is your current engaging industry? & $\begin{array}{c}\text { Settlement } \\
\text { Jabagly }(\%)\end{array}$ & $\begin{array}{l}\text { Settlement } \\
\text { Abaiyl (\%) }\end{array}$ \\
\hline Tourism & 10.2 & 3.6 \\
\hline Animal husbandry & 48.8 & 19.6 \\
\hline Farming & 23.6 & 12.5 \\
\hline Commercial activities & 10.8 & 10.7 \\
\hline Other industries & 6.6 & 53.6 \\
\hline \multicolumn{3}{|c|}{ What kind of industry do you think is suitable for in the Aksu-Jabagly NR? } \\
\hline Tourism & 52.4 & 67.9 \\
\hline Animal husbandry & 27.1 & 14.3 \\
\hline Farming & 16.3 & 7.1 \\
\hline Forestry & 4.2 & 10.7 \\
\hline \multicolumn{3}{|c|}{ What kind of industry do you want to engage if you have a reselect chance? } \\
\hline Tourism & 28.3 & 19.6 \\
\hline Animal husbandry & 31.3 & 32.1 \\
\hline Farming & 19.3 & 10.7 \\
\hline Commercial activities & 13.3 & 19.6 \\
\hline Other industries & 7.8 & 17.9 \\
\hline \multicolumn{3}{|c|}{$\begin{array}{l}\text { Do you think your advice should be acquired when conducting } \\
\text { tourism development strategies in the Aksu-Jabagly NR? }\end{array}$} \\
\hline Should ask & 38.1 & 21.4 \\
\hline It would be better & 45.3 & 37.5 \\
\hline I do not care & 12.9 & 35.7 \\
\hline No need & 3.7 & 5.4 \\
\hline
\end{tabular}

Comparison of residents' choice in a suitable industry: When answering the question about suitable industries in the Aksu-Jabagly NR, about half of the respondents who settled in Jabagly (52.4\%) and about two-thirds of the respondents who settled in Abaiyl (67.9\%) chose tourism. The second choice for respondents from the two settlements was animal husbandry, which accounted for $27.1 \%$ of Jabagly's population and $14.3 \%$ of Abaiyl's population. Jabagly's respondents considered the forestry as the least suitable industry (4.2\%), while Abaiyl's respondents thought farming as the least suitable industry (7.1\%) in the territory of the Aksu-Jabagly NR (Table 2). This means that although tourism is one of Kazakhstan's newly emerging industries, most people in Kazakhstan and even the country's rural people are aware of the economic, socio-cultural and environmental benefits of tourism development in the fragile biodiversity reserves.

Reselect industries comparison: Table 2 showed that there were approximately the same proportion of people in both settlements (Jabagly $-31.3 \%$ and Abaiyl - 32.1\% respectively), who chose "animal husbandry" for their reselect industry. $28.3 \%$ of Jaagly's respondents chose tourism for their reselect industry, while $19.6 \%$ of Abaiyl's respondents chose tourism. In terms of "farming and commercial activities", the result of choice was opposite in the two settlements. The number of people willing to engage in farming in Jabagly and commercial activities in Abaiyl were almost the same, with $19.3 \%$ and $19.6 \%$ respectively, while those willing to engage in commercial activities in Jabaly accounted for $13.3 \%$, and those who were willing to engage in farming in Abaiyl accounted for 10.7\%. The proportion of Jabagly residents who chose other industries was low (7.8\%), but nearly one-fifth of Abaiyl's residents chose other industries (17.9\%). More than half of the respondents in the two neighboring settlements believed that tourism is the most suitable industry to develop in this world heritage site, but for the question of reselect industries, most respondents in the two settlements chose animal husbandry as their first top wish. It means that although the locals in the two settlements believe that tourism is good in many ways, they actually want to engage in their old professions.

Comparison of residents' care about tourism development strategies: In response to a question about whether residents' advice was obtained when developing tourism in the Aksu-Jabagly NR, more respondents in the settlement Jabagly answered "Should ask" (38.1\%) and "It would be better" (45.3\%), however, the Abaiyl respondents' answers focused on "It would be better" (37.5\%) and "I don't care" (35.7\%). There were only 12.9\% of Jabagly's respondents selected "I don't care", and $21.4 \%$ of Abaiyl's respondents selected the answer "Should ask". The answer "No need" was selected in less proportion by people in both Jabagly and Abaiyl, with $3.7 \%$ and $5.4 \%$ respectively (Table 2). This means that compared with the Abaiyl settlement, more Jabagly settlers are concerned about the tourism development strategies in the Aksu-Jabagly NR. This is because there are more people engaged in tourism in Jabably than in Abayil (seen in Table 2).

\section{Comparison of the current and reselected industries in neighboring communities}

By comparing the respondents' reselected industries to the current industries (Figure 2), we found the following changes: 
The tourism industry was selected by $28.3 \%$ of Jabagly's residents and $19.6 \%$ of Abaiyl's people after they had a reselect choice. It is about 4 times more in Jabagly and about 5 times more in Abaiyl compared to the current engaging industry.

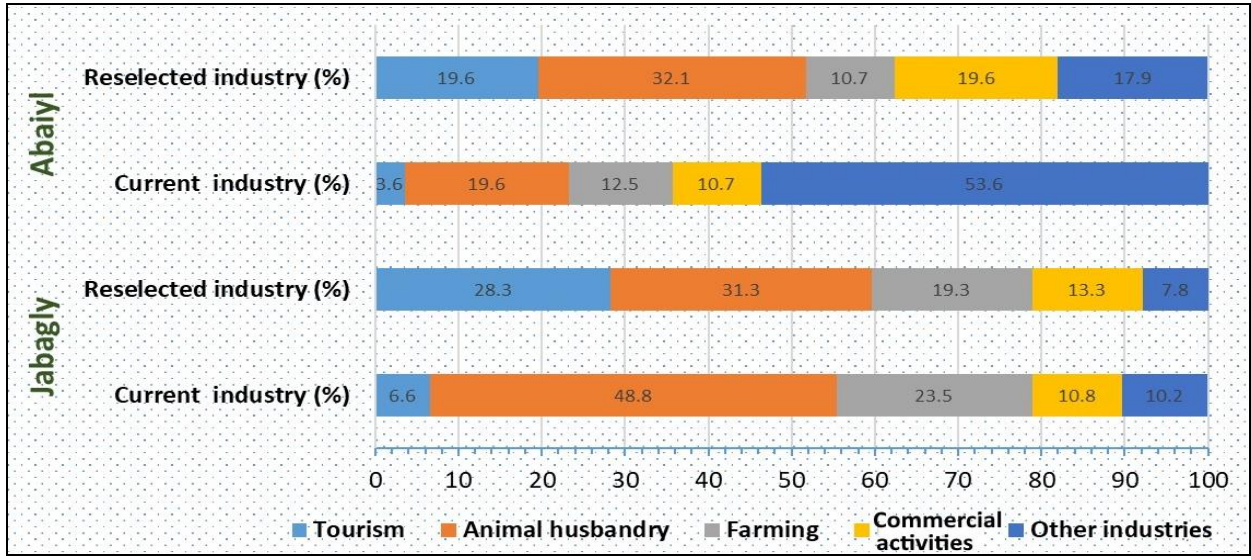

Figure 2. Comparison of the resident's current industries with the reselected industries
In addition, the proportion of reselected animal husbandry $(31.3 \%)$ is lower than that in the current industry $(48.8 \%)$ in settlement Jabagly, while the proportion of reselected animal husbandry $(32.1 \%)$ is higher than that in the current industry (19.6\%) in settlement Abaiyl. Then, there were not seen big changes in farming, commercial activities and other industries of Jabagly after reselecting, the proportion of farming and other industry slightly decreased (from $23.5 \%$ to $19.3 \%$ and from $10.2 \%$ to $7.8 \%$ respectively), but

commercial activities proportion increased a little (from $10.8 \%$ to $13.3 \%$ ). Finally, after reselecting, the proportion of other industry in Abaiyl has declined significantly (from 53.6\% to 17.9\%), at the same time, farming proportion somewhat decreased (from $12.5 \%$ to $10.7 \%$ ) and the proportion of commercial activities increased more (from $10.7 \%$ to $19.6 \%$ ).

It can be concluded from the changes above that, the main industries of Jabagly's community have become animal husbandry and tourism after re-selection, and the main industries of settlement Abaiyl is animal husbandry. The ideal industry for residents of the two settlements is "animal husbandry".

\section{Distance decay law and tourism relevance}

The purpose of distant villagers is to provide the tourism products that tourists need and compete with the local community for the market, which constitutes a competitive relationship with the residents who live adjacent to core tourist destinations (Sun, 2009). Distance decay is a term used in geography to describe the effects of distance on spatial or cultural interactions. Distance decay means that the interaction between locals declines as the distance between them increases.

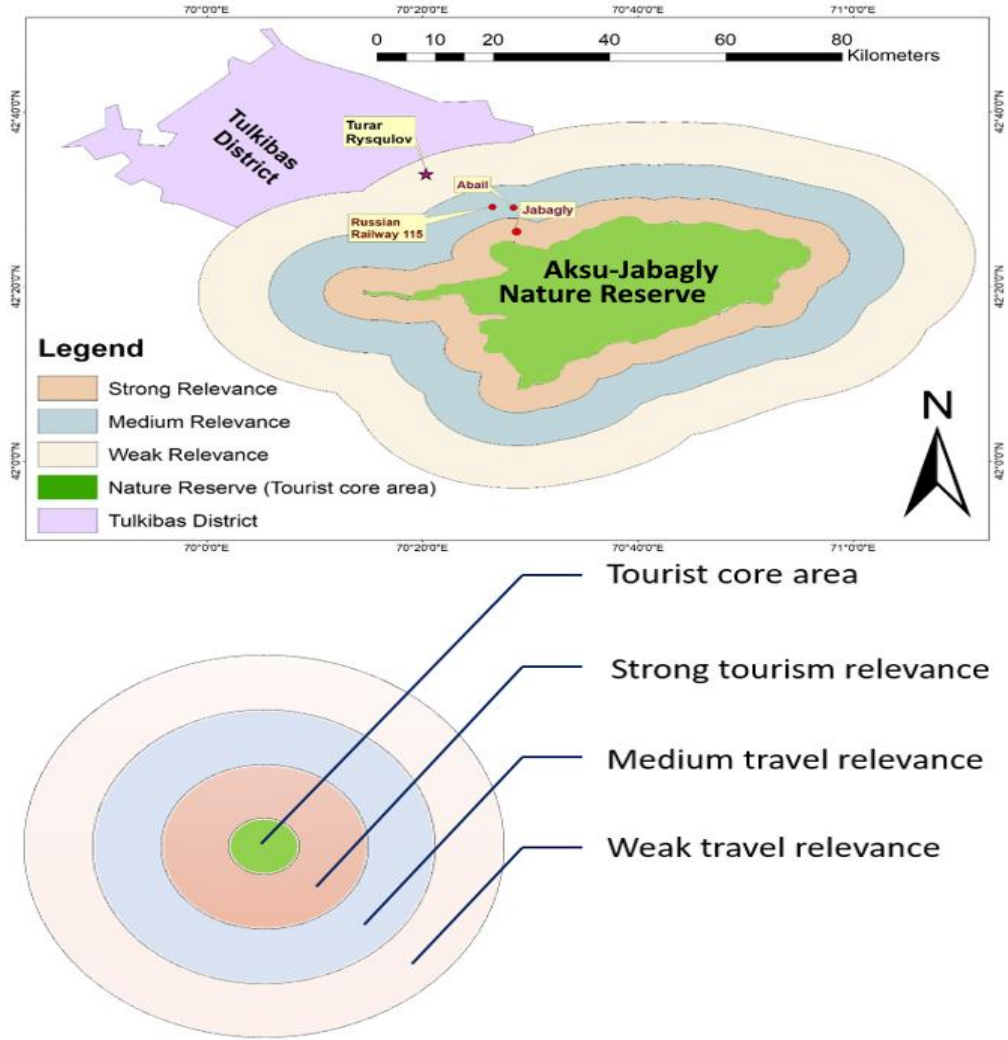

Figure 3. Sketch map of tourism correlation distance decay

In other words, if the distance between the two local communities increases, then their interactions decrease (Rengert et al., 1999). It can be seen in Table 2 that the level of tourism engagement, residents' wish of reselecting industries, and the residents' concerns about tourism development strategy were positively correlated with the distance of the Aksu-Jabagly heritage tourism destination. By comparing the level of tourism engagement, residents' wish of reselecting industries and the residents' concerns about tourism development strategies, we found that people who engaged in tourism in Jabagly (shorter distance from the core area) are more than those in Abaiyl (farther from the core area), of Jabagly residents' wish of reselecting industries is higher than Abaiyl residents', and there are more Jabagly's people concern about tourism development in the heritage site than Abaiyl's. Thus, it can be easily concluded that the smaller the distance from the community to the heritage site, the stronger the tourism relevance, and the stronger the tourism relevance, the higher level of tourism engagement, the more people have the wish to choose tourism as their reselect-industry, and the more people care about tourism development strategies in their neighboring area.

The farther the distance from the community to the tourism destination, the fewer people are willing to choose tourism as their re-selected industry, and fewer people care about the tourism development strategy of the nearby areas. 
Settlement Jabagly is the nearest point of the core zone of the Aksu-Jabagly NR, located in circle 2 and there is a strong tourism relevance between the community in settlement Jabagly and the Aksu-Jabagly NR, while settlement Abaiyl is located in circle 3, and the tourism relevance between the community and the NR is medium (Figure 3). One of the most primary reasons for this phenomenon is definitely the location. In terms of location, the relevance of CBET in the Aksu-Jabagly NR decreases in the following order: tourist hotspot - tourist hotline - tourist warm point - tourist cold spot. Settlement Jabagly is a "tourist hotline", located near the hot spots, so tourists must visit there, it has good scenery and the best location, and some community residents participate in the tourism industry. Thus the number of tourists is more in settlement Jabagly than that in settlement Abaiyl. In terms of settlement Abaiyl, because of longer-distance very few residents in this settlement participate to the tourism industry in the NR, the community of settlement Abaiyl belong to the "warm point". Some tourists visit this area and few community residents participate in tourism there. If the community residents have different locations from the core zone of the tourism destination, the level of community participation and tourism concerns will be different. A good location can enhance the tourism relevance of the community, thereby increasing the tourism engagement level of the communities, the communities' reselecting-tourism wishes and the communities' concerns about tourism development strategies.

\section{Participation rank of neighboring communities in tourism}

High level community participation is defined as a process by which people are enabled to become actively and genuinely involved in defining the issues of concern to them, in making decisions about factors that affect their lives, in formulating and implementing policies, in planning, developing and delivering services and taking actions to achieve change (Craswell et al., 2001). Being a developing nation, the status of tourism development, democratization, land ownership, and the civil organization's development in Kazakhstan are still at a low level. When we interviewed professor Ordenbek Mazbayev (a tourism researcher from the Eurasian National University of Kazakhstan) he said: "Local communities of tourism destinations in Kazakhstan are mostly in a shallow level of participation or non-participation: just participating in the field of economic activities, starting to have the interest-sharing appeal, but not exceeding the economic scope. As a rural local residents' participation in tourism, most people belong to a shallow level of participation due to their own limited abilities and other objective conditions. The community participation in tourism development at the Aksu-Jabagly NR is no exception".

\begin{tabular}{|c|c|}
\hline Level 1. & - Community receives benefits from the service but contribute nothing. \\
\hline Level 2. & $\begin{array}{c}\text { - Some personnel, financial or material contribution from the } \\
\text { community, but not involved in decision making. }\end{array}$ \\
\hline Level 3. & - Community participates in lower level decision making processes. \\
\hline Level 4. & $\begin{array}{l}\text { - Participation goes beyond lower level decision making to monitoring } \\
\text { and policy making. }\end{array}$ \\
\hline Level 5. & $\begin{array}{l}\text { - Program is entirely run by the community, except for some external } \\
\text { financial and technical assistance. }\end{array}$ \\
\hline
\end{tabular}

Figure 4. Stages of the community involvement in tourism
Figure 4 is the level of community participation in tourism development. The two levels below the figure (level 4 and level 5) belong to the advanced participation stage, and the above three levels (level 1, level 2 and level 3) are the primary participation stage. When we interviewed the scientific research department director of Aksu-Jabagly NR office, who knows local residents' participation situation in tourism of the Aksu-Jabagly NR well, he said:

"Local communities mainly involved in general hospitality services and participation in tourism distribution, catering, accommodation, entertainment, transportation, etc. Although they are sometimes invited the meetings of decision making about tourism planning and management in their area to allow giving their suggestion to some degree, no community residents are involved in tourism administration at a higher level or entirely. " It can be seen from the above-mentioned fact that the communities of Jabagly and Abaiyl are still in the low-level stage of the community participation hierarchy.

\section{Empowerment of neighboring communities}

Community tourism usually creates a unique view of the importance of community participation in rural development, which in turn leads to increased community capacity (SETOKOE, 2021). Most research in Western countries focuses on community's participation in decision-making, especially the tourism planning process (Gunn and Var, 2002). Community empowerment is a process of re-negotiating power in order to gain more control, and it recognizes that if some people are going to be empowered, then others will be sharing their existing power and giving some of it up (Baum and Groeling, 2008). The ideal Western-style 'community participation' approach can be examined from at least two perspectives: decision-making and tourism benefit sharing (McIntosh and Goeldner, 1986). Community empowerment, therefore, is more than the relevance, participation or engagement of communities. It implies community ownership and action that explicitly aims at social and political change. However, professor Ordenbek Mazbayev also said: “Due to Kazakhstan's social reality, on the one hand, rural community participation in higher stages of tourism-participation, such as decision making and tourism planning, has not been recognized as important in tourism industry; and on the other hand, many rural residents do not desire to be involved in regional tourism decision-making and management.". According to the results of the tourism relevance questionnaire survey of the two neighboring communities and the analysis of community participation rank above sections, we knew that the tourism relevance of the neighboring communities with Aksu-Jabagly heritage tourism destination was low, and their overall participation was at the lower level. As a result, we can say that communities of Jabagly and Abaiyl settlements, like other rural areas' communities in Kazakhstan, are not well prepared for an active public participatory approach in decisionmaking, planning and management of tourism activities. For "empowerment", there are two definitions, one is to enhance 
the understanding of individual abilities and rights through external intervention and help to red uce or eliminate the process of powerlessness. The ultimate goal is to point to the social action of acquiring rights and the resulting structure of social change (Clark and Zimmerman, 1990); the other is defined as an action-process that builds awareness, empowers and develops skills, leads to greater participation, greater equality, and greater impact (Sun and Ma, 2012). The meaning of community empowerment is reflected in the economic, socio-cultural and political aspects, as shown in Figure 5. Through community empowerment, residents' incomes will increase, community infrastructure will gradually improve, economic and social benefits will be improved, and residents will become the biggest beneficiaries. Participation in decision-

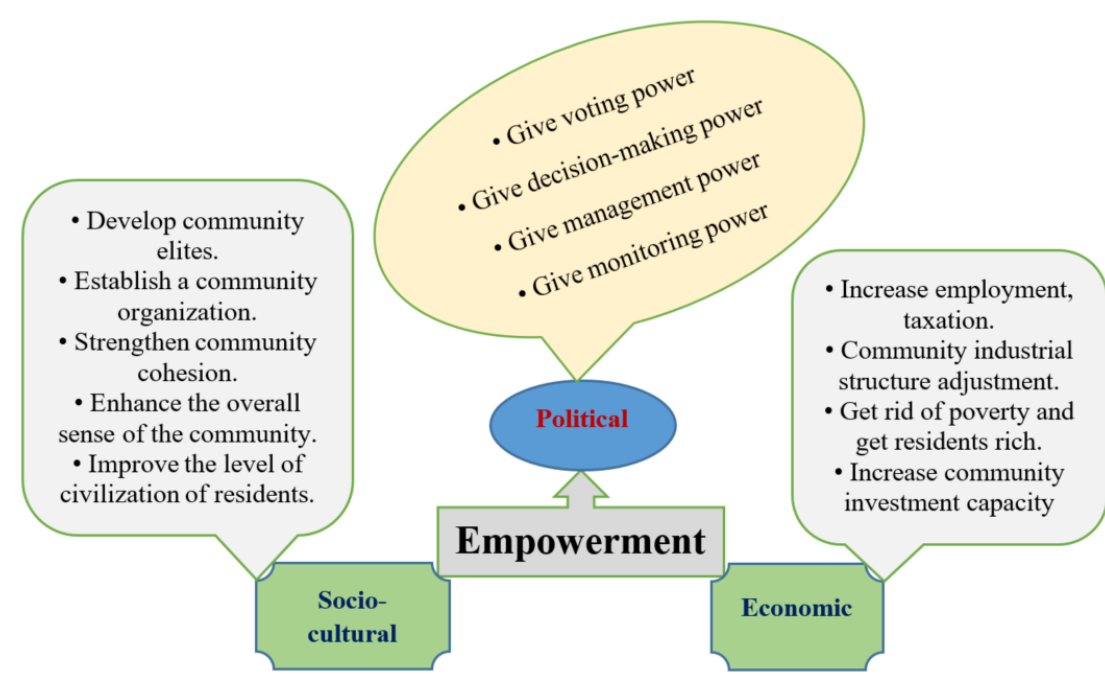

Figure 5. The significance on the empowerment of the local communities making generally refers to empowering local residents to determine their hopes and concerns for tourism (Timothy and Tosun, 2003). According to the locus of the right to tourism development and operation, there are two general modes of rural communities' tourism development: top-down and bottom-up. The former refers to those dominated by local governments, corporations or nongovernmental organizations (NGOs); the latter refers to those dominated by local residents or migrants in rural communities (Huang and Chen, 2020). It can be concluded from the above-discussion that foreign residents have relatively large rights in community participation while Kazakhstan communities' participation in tourism and residents' rights are weak. The scientific research department director

of Aksu-Jabagly NR office also said: "The tourism activities in the core zone of the heritage site have been strictly controlled and monitored by the heritage management office. Although it is said that the chance of tourism development in the buffer zone gives everyone equally, tourism planning and organizing events in the buffer zone have been monopolized by very few business-skilled and politically powerful people, some of whom are not local residents". Therefore, we can claim that in accordance with its law Kazakhstan is a democratic country like western states, the government or other political parties have empowered their community or citizens, every citizen of the Republic of Kazakhstan has the privilege to participate in events holding around them, and bottom-up management should be applied in the decision making, however, community residents' rights are always limited, their enthusiasm to participate in various economic activities including tourism development is very low, and the top-down management of governments, corporations or NGOs plays a primary role in CBET development at the Aksu-Jabagly NR.

To study the relevance of the neighboring communities with tourism is fundamental to evaluate the sustainable development of nature-based tourism or ecotourism, because the communities adjacent to the nature tourism area are the first owners of the area, they have the right to receive a large share of economic benefits from there, and the participation of the local community is very important in terms of environmental protection. Tourism in protected areas occurs in remote rural areas, it is generally believed that these areas will experience the stimulation of economic activities caused by tourism, and the local people will receive tangible benefits from tourism development (Nepal, 1997). The result of the questionnaire survey regarding tourism relevance of neighboring communities at the selected research area showed that despite the fact that a small number of local residents in the settlements of Jabagly and Abaiyl were engaging in the tourism activities, more than half of the population in both communities considered tourism as the most suitable industry for developing in the heritage site and cared about the tourism development strategies in the heritage site. At the same time, according to their reselect-industry wish, a relatively high number of locals have a desire to participate in the development of tourism. It means that based on the situation of these two communities, if the majority of the people chose tourism for the answer of the suitable industry and people chose tourism as their second wish for the answer of the reselect industry, we will see that those residents are highly motivated to believe in future benefits of tourism and to participate in tourism. According to the documents of Kazakhstan National Committee for the UNESCO Program "Man and Biosphere" and Nomination Dossier of Western Tien-Shan, local communities should be involved in the development and management plans of the biosphere reserve. However, professor Ordenbek Mazbayev said: "Due to their low educational level, corruption, monopoly, and lack of competitiveness, limited management and operational capabilities, they have not participated well in tourism development management plans in rural areas.". If rural areas are developed as tourism destinations, local community rights to local resources do not change, and as local owners, the local community has the right to use and prioritize the community's tourism resources. They have the right and obligation to participate in the development and protection of local community tourism resources, the right to participate in tourism development decisions and the right to obtain tourism income fairly. Our results also reveal that although the community residents of village Jabagly are the owners of the heritage sites, part of the tourism resources and providers of human resources, the tourism participation level and empowerment status of the main neighboring communities are still low.

In our article, we have analyzed the three indicators (tourism relevance of the neighboring communities; participation rank of neighboring communities; empowerment of neighboring communities) when assessing the sustainability of CBET 
in the Aksu-Jabagly NR. From the analysis of them, we can draw the following conclusions: The development of tourism in the Aksu-Jabagyl heritage tourism destination does not meet the requirements of sustainable development of tourism in rural areas, in particular, fails to maintain the economic and social sustainability of tourism development. The tourism industry has the potential to promote sustainable development, especially through the creation of jobs, including employment for women and marginalized groups (Cukier, 2002). The purpose of sustainable tourism is to achieve a balance between protecting the environment, maintaining cultural integrity, establishing social justice and promoting economic interests, at the same time, to meet the needs of the host country's population in terms of improving short-term and longterm living standards (Liu et al., 2013). After observing the study area, we witnessed that the development of sustainable tourism has been implemented in the neighboring communities of Aksu-Jabagly NR to some degree, where some tourist companies and several local residents operate tourism business and they receive tourists every year. They hire several local residents and help increase the local community's economic income. But, unfortunately, despite the fact that there are great opportunities for realizing the economic and social sustainability of tourism development, not many people of neighboring communities engaged in the tourism industry actively and did not see the real economic and social benefits.

Economic sustainable development provides the basis for the efficient use of local resources, while ecologically sustainable development emphasizes the need for effective conservation of biological diversity (Joseph et al., 2020). Considering the environmental effects of sustainable tourism, we are pleased that according to the research results, many people believe that the development of tourism is more effective than other industries in maintaining the ecology of this world heritage site. And when observing the study area, we saw that comparatively higher proportion of local residents are employed by the NR administration office to effectively protect the biosphere in the reserve. They work hard every day, sometimes, workers live in the core zones of the NR for several days to check the wild animals' safety.

As a result, due to the above-mentioned strict regulations and cognitive ideological measures, despite the fact that the NR has been established for nearly a century, the ecology of it is still intact. Through discussing some issues of the relevance of neighboring communities with tourism, participation rank in tourism and the empowerment of the neighboring communities, we initially assessed the development status of CBET at the Aksu-Jabaly NR in Kazakhstan. It helps to conceptualize the socio-economic value of NRs, demonstrate its utility and promote knowledge with practical policy implications in various ways. In this process, it provides innovative theoretical contributions by unifying the relevant fields of NR tourism research and sustainable tourism development, emphasizing the needs to provide more empirical evidence for issues studied through specific case studies. Exploring the development status of the CBET development is accomplished by a mixed-method approach in the case of the Aksu-Jabagly NR in Kazakhstan.

\section{CONCLUSION}

The study concludes that the tourism relevance of two main neighboring communities of Aksu-Jabagly tourism destination is comparatively low because very few people engage in the tourism industry at present. At the same time, the local community participation rank and empowerment level of the local community are low too. It indicates that the development of CBET in Aksu-Jabagly NR is still at the lower stage. Improving local communities' tourism relevance, participation rank and empowerment level should aim at increasing economic, social and environmental benefits of nature based tourism. Therefore, in order to increase the local communities' participation level in the tourism industry, first, local governments or relevant organizations should arrange regular training to improve the knowledge of local communities about engaging in tourism. Second, the local communities' experience of organizing tourism should be accumulated by providing opportunities for engaging in tourism activities and the government provides them with financial and policy support when they are incapable. Finally, if the community has its own source of funds and has certain talents and experience, at the same time, the relevant administrations establish a pleasant environment for them, then the community can manage and operate the heritage tourism itself. There is no doubt that empowering communities will lead to an increase in the level of community participation and tourism relevance, which is definitely the prerequisite of community-based tourism development, a guarantee of gaining the fundamental interests of surviving and developing for the local community, and the foundation of implementing a fair development concept. Although Kazakhstan has a favorable geopolitical position, natural and recreational resources and world cultural and historical heritage, it is not competitive with countries known for tourism and travel (Aktymbayeva et al., 2020). As we have seen in our research, one of the main reasons for this is the low development level of community-based tourism in rural areas, which attracts more tourists.

The main limitation of this study is to evaluate the status of the sustainability of tourism development in the study area by analyzing and discussing limited number of indicators, such as tourism relevance of neighboring communities, their participation rank in tourism and the empowerment status of them, and interviewing the most representative stakeholder groups for quantitative and qualitative analysis, namely local residents and some relevant experts, which are not fully representative of the entire population of stakeholders in the Aksu-Jabagly tourist attraction. In addition, empirical research is biased due to the use of a single case study, the research's time framework and budgetary constraints. A single case study could give some new ideas or theoretical propositions, but may not be an effective basis for laying a general theoretical foundation. Further researches can be carried out based on the current findings to obtain more precise strategies to improve the management of natural heritage sites and to promote the sustainable development of nature-based tourism in protected areas of Kazakhstan.

Aknowlegments

WE acknowledge Zhumanova Elmira Perdebaevna, the head of environmental education and tourism department of AksuJabagly state nature reserve, who provided great help during the field and social surveys in the Aksu-Jabagly tourism destination. 


\section{REFERENCES}

Akbar, I., Yang, Z., Han, F., \& Kanat, G. (2020a). The influence of negative political environment on sustainable tourism: A study of aksujabagly world heritage site, kazakhstan. Sustainability, 12, 143. https://doi.org/10.3390/su12010143

Akbar, I., Zhaoping, Y., Mazbayev, O., Seken, A., \& Udahogora, M. (2020b). Local residents'participation in tourism at a world heritage site and limitations: a case of Aksu-Jabagly natural world heritage site, Kazakhstan. GeoJournal of Tourism \& Geosites, 28. https://doi.org/10.30892/gtg.28103-450

Aktymbayeva, B., Koshkimbayeva, U., Abisheva, Z., Tokbergenova U., \& Tumazhanova, M. (2020). Tourism industry development and governance: a comparative stage review of Kazakhstan's experience for the years of independence, 1991-2020. GeoJournal of Tourism and Geosites, 34, 69-76. https://doi.org/10.30892/gtg.34110-621

Alexander, S.E. (2000). Resident attitudes towards conservation and black howler monkeys in Belize: the Community Baboon Sanctuary. Environmental conservation, 341-350. https://doi.org/10.1017/S0376892900000394

Baum, M.A., \& Groeling, T. (2008). New media and the polarization of American political discourse. Political Communication, 25, $345-365$. https://doi.org/10.1080/10584600802426965

Clark, N.M., \& Zimmerman, B.J. (1990). A social cognitive view of self-regulated learning about health. Health Education Research, 5, 371379. https://doi.org/10.1177/1090198114547512

Craswell, N., Hawking, D., Vercoustre, A.M., \& Wilkins, P. (2001). P@ noptic expert: Searching for experts not just for documents. In Ausweb Poster Proceedings, Queensland, Australia, 17. http://www.ted.cmis.csiro.au/publications/01/Ausweb01.ps

Cukier, J. (2002). Tourism employment issues in developing countries: examples from Indonesia. Tourism and development: Concepts and issues, 165-201.

Denman, R. (2001). Guidelines for community-based ecotourism development. WWF International Gland, Switzerland.

Gunn, C.A., \& Var, T. (2002). Tourism planning: Basics, concepts, cases. Psychology Press.

Hipwell, W.T. (2007). Taiwan aboriginal ecotourism: Tanayiku natural ecology park. Annals of Tourism Research, 34, 876-897. https://doi.org/10.1016/j.annals.2007.04.002

Kovshar, A. (2016). Aksu-Zhabagly nature reserve's 90-anniversary. Nature conservation research, 1, 111-118. [In Russian]. http://dx.doi. org/10.24189/ncr.2016.011.

Huang, S., \& Chen, G. (2020). Handbook on Tourism and China. Edward Elgar Publishing.

Joseph, E.K., Kallarakal, T.K., Varghese, B., \& Antony, J.K. (2020). Sustainable tourism development in the backwaters of south Kerala, India: the local government perspective. GeoJournal of Tourism and Geosites, 33, 1532-1537. https://doi.org/10.30892/gtg.334spl13-604

Khanal, B.R., \& Babar, J.T. (2007) Community based ecotourism for sustainable tourism development in the Mekong region. Policy Brief, 1.

Kiss, A. (2004). Is community-based ecotourism a good use of biodiversity conservation funds? Trends in ecology \& evolution, 19, $232-237$. https://doi.org/10.1016/j.tree.2004.03.010

Liu, C.H., Tzeng, G.H., Lee M.H., \& Lee, P.Y. (2013). Improving metro-airport connection service for tourism development: Using hybrid MCDM models. Tourism Management Perspectives, 6, 95-107. https://doi.org/10.1016/j.tourman.2011.05.002

Mbaiwa, J.E. (2003). The socio-economic and environmental impacts of tourism development on the Okavango Delta, north-western Botswana. Journal of arid environments, 54, 447-467. https://doi.org/10.1006/jare.2002.1101

McIntosh, R., \& Goeldner, C. (1986). Tourism-principles, practices, philosophies, New York: John Wiley \& Sons.

Nepal, S.K. (1997). Sustainable tourism, protected areas and livelihood needs of local communities in developing countries. The International Journal of Sustainable Development \& World Ecology, 4, 123-135. https://doi.org/10.1080/13504509709469948

Polnyotee, M., \& Thadaniti, S. (2015). Community-based tourism: A strategy for sustainable tourism development of Patong Beach, Phuket Island, Thailand. Asian Social Science, 11, 90. https://doi.org/10.5539/ass.v11n27p90

Powell, R.B., \& Ham, S.H. (2008). Can ecotourism interpretation really lead to pro-conservation knowledge, attitudes and behaviour? Evidence from the Galapagos Islands. Journal of sustainable tourism, 16, 467-489. https://doi.org/10.1080/09669580802154223

Reimer, J.K., \& Walter, P. (2013). How do you know it when you see it? Community-based ecotourism in the Cardamom Mountains of southwestern Cambodia. Tourism Management, 34, 122-132. https://doi.org/10.1016/j.tourman.2012.04.002

Rengert, G.F., Piquero, A.R., \& Jones, P.R. (1999). Distance decay reexamined. Criminology, 37, 427-446. https://doi.org/10.1111/j.17459125.1999.tb00492.x

Salafsky, N., Cauley, H., Balachander, G., Cordes, B., Parks, J., Margoluis, C., Bhatt, S., Encarnacion, C., Russell D., \& Margoluis, R. (2001). A systematic test of an enterprise strategy for community-based biodiversity conservation. Conservation biology, 15, 15851595. https://doi.org/10.1046/j.1523-1739.2001.00220.x

Setokoe, T.J. (2021). Community-based tourism: a panacea for community development in nqileni village, eastern cape, South Africa. GeoJournal of Tourism and Geosites, 34, 28-32. https://doi.org/10.30892/gtg.34104-615

Stronza, A., \& Gordillo, J. (2008). Community views of ecotourism. Annals of tourism research, 35, 448-468. https://doi.org/10.1016/j.annals.2008.01.002

Timothy, D.J,. \& Tosun, C. (2003). Arguments for community participation in the tourism development process. Journal of Tourism Studies, $14,2,1035-4662$.

Törn, A. (2007) Sustainability of nature-based tourism. http://urn.fi/urn:isbn:9789514286674

Walpole, M.J., \& Goodwin, H.J. (2001). Local attitudes towards conservation and tourism around Komodo National Park, Indonesia. Environmental conservation, 160-166. https://doi.org/10.1017/S0376892901000169

Williams, P.W., \& Fennell, D.A. (2002). Creating a sustainable equilibrium between mountain communities and tourism development. Tourism Recreation Research, 27, 5-8. https://doi.org/10.1080/02508281.2002.11081369

Wood, M. (2002). Ecotourism: Principles, practices and policies for sustainability. UNEP. http://hdl.handle.net/20.500.11822/9045

Sun, J. (2009). Community Tourism and Community Participation in Tourism Anthropology. Business Press. [in Chinese].

Sun, J., \& Ma, T. (2012). "Relocalization" and "Delocalization" of Ethnic Culture in Tourism Development: Taking Lijiang Naxi Yishang Community as an Example. Journal of Guangxi University for Nationalities: Philosophy and Social Science Edition, 34, 60-67, [in Chinese]. https://www.cnki.com.cn.

*** Kazakhstan National Committee. (2014). Kazakhstan National Committee for the UNESCO Programme "Man and Biosphere": AksuZhabagly BIOSPHERE RESERVE. http://www.unesco.org

*** Organization, U. N. W.T. (2001). Compendium of Tourism Statistics. UNWTO Madrid. https://www.e-unwto.org/doi/pdf/10.18111/9789284406845 